\title{
THE PHENOMENON OF CARING BY THE MIDWIFE
}

\author{
A.G.W. Nolte
}

\section{TIIE NECESSTTY OF TIIE STUDY AND TIIE RESEARCII PROBLEM}

Many changes have taken place in midwifery during the last half of this century. - The whole structure of the family has changed from that of a supporting extended family to a nuclear family causing the family to start new roles as parents without the support of older family members. This may lead to feelings of insecurity and anxiety.

- Antenatal care, the delivery and postnatal care in the past, occurred at home. The familiarity of the home, logether with involvement of other family members were a source of security. Today, care has moved to the doctor's surgery or hospital, where technology plays an important role. This enhances the new family's feelings of insecurity and isolation in their new roles.

- The continuity of care available prenatally and throughout the birth process often comes to an abrupt halt during the postnatal period, especially after the discharge of the mother and baby from hospital. Mothers and babies are often discharged on the second to fifth postpartum day (Sheehan, 1981:19; Ball, 1987:137) and the new mother may be sent home with minimum support and direction. During this period, particularly, the mother has many questions about the baby's behaviour and the care she provides (Sumner \& Fritch, 1977:27).

Child-bearing events are normal physiological processes in the body of the woman and embryo-foetus/baby. Many changes in the internal and external environments of the family take place alongide these normal processes which lead to tasks and responsibilities that must be accomplished successfully during the child-bearing events.

When the family comes into contact with the midwife their insecurity causes them to look to her for help and support.

\section{Questions which arise are:}

- What are the caring activities which the midwife should carry out to assist and facilitate the new family to grow on the health continuum during the postnatal period?

\section{Opsomming}

Die kindergeboorte periode is 'n periode waariydens normale fishiologiese prosesse in die liggaam van die moeder en embrio/foetus/baba plaasvind. Saam met bogenoemde prosesse vind daar ook baie veranderinge in die interne en ekstarne omgewings van die moeder plaas. Al die veranderinge lei tot die ontwikkeling van bepaalde take en verantwoordelikhede wat suksesvol deur die familie tydens die kindergeboorte gebeure afgehandel moet word.

Daar het ook baie veranderinge in die vroedwou se prakyk plaasgevind oor die afgelope tyd. Hierdie veranderinge, saam met die veranderinge in die familie, mag gevoelens van onselauriteit by die nuwe familie gedurende die stadia veroorsaak.

Hierdie gevoelens van onsekuriteit lei dikwels daartoe dat die familie na die uraedurou opsien vir hulp en ondersteuning.

Die vrae wat ontstaan is dus:

- Watter sorg-aktiwiteite moet die vroedvrou uitvoer om die familie se groei op die gesoudheidskontinuum aan te help en te fasiliteer?

- Hoe kan die humanistiese waardes van sorg gekombineer word met die wetenskaplike kenuisbasis wat die aksies van die vroedvrou rig om die wetenskap van "sorg" 1 vorm?

in Besknywing van die vroedwrou se sorg aktiwiteite gedurende die nageboorte bydperk in die hospitaal sowel as na ontslag in die gemeenskap is dus essensieel.

\section{Abstract}

The child-bearing events are normal physiological processes in the body of the woman and embryo-foetusibaby. Many changes in the internal and external environments of the family take place, simultaneously with these normal processes. These changes lead to the development of certain tasks and responsibilities that must be successfully accomplished by the family during the child-bearing events.

Many changes have also taken place in midwifery during the last half of this century. These changes in midwifery practice, together with the changes that take place during child-bearing events, may cause the new family to feel insecure during this stage of their lives.

Very often when the family comes into contact with the midwife the factors contributing to feelings of insecurity are present already or soon become present. Their insecurity causes the family to look to the midwife for help and support.

The questions that arise are:

- What are the caring activities which the midwife should carry out to assist and facilitate the new family to grow on the health continuum during the posmatal period?

- How can the humanistic values of caring be combined with the scientific knowledge base that guides the midwife's actions to form the science of caring?

A description of the midwife's caring functions during the post-natal period, in the hospital as well as in the communin, is therefore essential. Thereafier, formulation of ualid standards for postnatal care by the midwife can contribute to quality post-natal care in South Africa.

- How can humanistic values of caring be combined with the scientific knowledge base guiding the midwife's actions? 
A description of the midwife's caring functions during the postnatal period, in hospital as well as in the community, is presented, after which midwifery standards for postnatal care can be formulated.

\section{TIIE AIM OF TIIE STUDY}

The aim of the present study is to:

- present a model for care rendered by the midwife to the new family which is the focus of this article.

- formulate valid general standards for postnatal care by the midwife to be the focus of a subsequent article.

\section{DESIGN OF TIIE RESEARCII}

A descriptive design was used to explore variables for postnatal care within this country.

The main goal of the first aim was to describe the phenomenon of caring by the midwife during the child-bearing period and the following methods were followed:-

- identification of concepts;

- statement of assumplions about, and analysis of such concepts;

In analysing the phenomena:

a) a literature study of existing caring models was done;

b) a text analysis was executed in order to identify the prerequisites and characteristics of caring;

c) a word analysis of the central characteristics was done by means of dictionaries;

d) a description of the prerequisites and characteristics for caring of the child-bearing family by the midwife in this Country.

A model for postnatal care based on identified prerequisites and characteristics of caring was designed.

\section{DEFINITIONS AND ASSUMPTIONS}

Person is a unique, God-created spiritual being who functions in an integrated biopsychosocial manner to achieve his quest for wholeness. Each person though a unique individual, is an integral member of a family, group and community (ORU,1989).

Parameters of midwifery include the individual, the family and the community, closely related to one another. The family during the child-bearing period is a basic unit of society consisting of a mother (or becoming mother), an embryo/foetus/baby and, when present, persons who are emotionally or structurally closely related to the mother. (The third person or persons may sometimes be absent).
The family has certain structural and functional components which are determined by culture; as a social unit it has affective, socialisation and social placement, health-care, reproductive and economic functions.

Family members who are interdependent and very closely interrelated, are in constant interaction with one another and with their internal and external environments. Changes in the external and internal environments lead to the development of certain tasks that must be successfully completed in order for growth to be accomplished.

The desired oulcome of midwifery centres around health as a state of spiritual, mental and physical wholeness which may be qualitatively described on a continuum from maximum to minimum health.

Illness is a dynamic state reflecting the nature of the person's interactive patterns with stressors in his internal and external environment. Illness can be qualitatively described as a continuum from scvere illness to minimum illness. Health potential exists in those who are ill (ORU, 1989).

Internal environment includes the body, mind and spirit of the individual (ORU, 1989).

External environment includes the physical environment, social environment and spiritual environment (ORU, 1989).

Assumptions from the theories such as these of Leininger's multi-cultural caring theory, Watson's caring theory, Orem's selfcare theory and Kotzé's accompaniment model were used in developing an appropriate model of care.

Importantly, it was assumed that the child-bearing events (pregnancy, childbirth and puerperium are normal physiological processes and that certain changes take place in the internal as well as external environment of the new family during the childbearing phase.

The midwife is a person who has successfully completed a midwifery educational programme recognized in the country in which it was located, and who has obtained the qualifications to be registered and/or legally licensed to practise midwifery. (WHO, International Federation of Midwives, Federation of International Gynaecologists and Obstetricians). The midwife functions as an independent practitioner on her own and as a member of a multidisciplinary health team. She functions within the practical, legal, philosophical and ethical framework of nursing and midwifery.

Midwifery is a scientific goal-direcled service to assist the individual, family and/or community to promote, maintain and restore health during the child-bearing period (ORU, 1989).

- Maintenance of health refers to those midwifery activities directed towards continuing or preserving the health status of individuals, families and/or communities

The parents are usually the mother and father of the baby. (In some cultural groups, another family member or members may take over the role of the parents after the birth of the baby).

The mother is the woman who gave birth to the baby. The father is usually the male who shares the pregnancy with the mother, biologically, psychologically and spiritually.

Child-bearing events are all the events that take place in the life of the new family from conception to six weeks after the birth of the baby. The postnatal period is the period from the birth of the baby to six weeks after the birth of the baby

Growth in this research will mean growth on the health continuum in the direction of maximum health.

\section{DEFINITION AND OBJECTIVES OF CARE BY TIIE MIDWIFE}

Changes in the external and internal environments of the individual members of the family, as well as the family as a unit, during the childbearing period lead to the development of certain unique health related problems and needs that must be successfully met in order for growth on the health continuum to be accomplished.

Through a scientific caring process, the midwife assists them and acts as a facilitator in their efforts to grow. The care takes place in the hospital, health clinics, homes of the families, and in the community.

The following aspects are an indication that growth has taken place during the child-bearing phase:

- An optimum level of physical health in both mother and embryo/foetus/baby, as well as in other family members.

- Parents accept their role as parents of this particular baby. The experience becomes meaningful, unique and valuable to them (Frankl 1955:48).

- The preservation of human dignity and humanity wherein the family determine their own meaning.

- The family members have a realistic perception and concept of themselves and their abilities, and accept themselves, their bodies and their abilities as parents and children.

* Family members are able to identify their feelings and express them in a healthy way which leads to good relationships between adult family members as well as between parents and their unborn/born baby. 
- Family members take responsibility, individually and as a unit, to promote, maintain and restore their own heal th, as well as the health of their unborn/born baby. They make use of their rights and responsibilities to participate actively in decisions about their health and health care during the child-bearing phase.

The interaction between the internal and external environments, the perception of care by the midwife and the amount of growth that will take place will be determined by the values and beliefs, the sources of support and levels of knowledge and development of the family (Watson, 1979:11; Leininger, 1988a:9).

\section{PREREQUISITES FOR TIIE MANIFESTATION OF CARE}

Unconditional acceptance of the other person/family and their values is absolutely essential before the caring relationship can be established.

The midwife must accept and respect the individual's uniqueness in the experience of external and internal environmental changes, his/her search for meaning and the need to grow. She accepts and promotes the family's rights and responsibilities to participate actively in decisions about their health and health care.

An essential characteristic of caring is therefore the protection of human dignity and the preservation of humanity (Watson, 1979:11) by acknowledging the family's potential.

Caring can only take place in a warm, trusting relationship between family and midwife. If the family are to grow through care they must trust the carer, for only then will they be able to open themselves. Without trust they will be closed and defensive.

The following aspects are important in the establishment of such a relationship by the midwife:

- The unconditional acceptance of the other person and respect for him as a person and the acceptance of the person's values (Kotze, 1979:177; Boyle, 1988:44).

- The sincerity and willingness of the midwife to care by way of her attitude, availability, presence, spending time with the family and interest (Kotze, 1979:177; Ray, 1988:31), as well as her values concerning kindness, concern, love of self and others.

- Geniuneness (Boyle, 1988:44) and congruence - based on the midwife being what she seems to be (Watson, 1979:28).

- Empathy (Boyle, 1988:44); she apprehends the other's reality, feeling what she feels as nearly as possible (Noddings, 1984:30-31).

- Non-possessive warmth which is related to unconditional positive regard which means the midwife values the person in total rather than in a unconditional way that includes not judging and not evaluating the other person's feelings (Watson, 1979:30).

- The correct utilization of communication skills.

Leininger (1988b:101) distinguishes between humanistic and scientific caring. Caring by the midwife is both scientific and humanistic.

Humanistic caring is the subjective feeling experiences and interactional behaviours between two or more persons in which assistive or enabling acts are performed generally without prior sets of verified or tested knowledge.

Scientific caring refers to those tested activities and judgements in assisting an individual or group based upon verified and quantified knowledge related to specific variables.

Caring by the midwife requires knowledge and understanding of individual needs, and of health-related problems or potential problems, knowledge of how to respond to others' needs, knowledge of her own strengths and limitations, of who the other person is and of her strenths and limitations, the meaning of the situation for her and knowledge of how to offer compassion and empathy (Watson, 1979:76-79).

Lack of appropriate knowledge is the main difference between a professional carer and the lay carer. The lay carer, in recognizing her limitations, is making a request to more knowledgeable and skilful agents. By acknowledging her limitations, the lay carer acknowledges that she is no longer able to provide appropriate care (Kitson, 1987:159).

The family who are in a developmental process, are involved in gathering knowledge about the next developmental stage towards which they are progressing. The midwife already has this knowledge. The midwife's scientific knowledge, together with her knowledge of the family's growth potential, gives her the ability as well as the responsibility to guide the family on their way to growth. (Kotzé, 1979: 174-176). The family, however, have freedom of choice and may choose whether or not they want to accept guidance from the midwife.

A caring environment is one that offers the development of potential, while at the same time allowing the person to choose the best action for self-fulfilment (Watson, 1979:10).

Caring involves an attitude and feelings aspect and an activities and cognitive aspect. These two are complementary (Griffen, 1983: 291). The following feelings should accompany caring:

- Devotion is essential. Such devotion expresses the entire person of the midwife rather than only her intellectual or emotional part. It is however, not intense nor pervasive of the life of the one caring. It is shown by consistency and persistence under unfavourable circumstances and a willingness to overcome difficulties (Mayeroff, 1971:8-9).

Engrossment is not characterized by emotional feelings but rather as rational objectivity. In caring, a permanent and untimely move from feeling and affective engrossment to abstract problemsolving would be a degrading movement from the appropriate to something qualitatively different and less appropriate. A temporary movement into objective thinking would however not necessarily be a degradion. The midwife should retain the ability to move back and forth and to investigate the appropriate mode (Noddings, 1984:35).

- A selflessness that is different from the loss of oneself in a panic situation or through conformity. It includes heightened awareness and greater responsibility to the other and yourself (Mayeroff, 1971:29). It is, however, not self-sacrificing - the carer does not give up her own needs. It has the unconditional aspects of agape love without sacrifice.

- Affection refers to the desire for another's welfare including commitment to act on behalf of the cared for, and a continued interest in his reality. (Ray, 1988:31-32; Noddings, 1984:33). Affection is not necessarily linked to a person's character you may feel affection towards somebody without liking him.

Caring is impossible if the carer is continually being replaced - the other must remain constant because caring is a developmental process. If it does not last long enough for any sense of loyalty to develop, powers like devotion and trust do not have the opportunity to develop. The cared for must also feel that the carer is constantly available to care for them, otherwise feelings of insecurity may arise (Mayeroff, 1971:34).

Caring may or may not be reciprocated (Mayeroff, 1971:36). The carer always hopes that what she gives will be received and accepted by the cared for and that they will then react upon it but it does not always happen in that way. Although the midwife is always supposed to care according to the family's needs, there may be a difference in the perception of needs by the midwife and family. This may cause the family not to receive or accept the care, either because they do not realise that they have a need, or because the midwife made an incorrect assessment hastly, the midwife should understand the meaning that parenthood has for the family: nobody can give the parents the meaning of their lives for they alone must create and discover it. Parents experience problems in acccepting the responsibilities of parenthood if they do not 
understand the meaning of parenthood in their lives.

\section{TIIE PROCESS OF CARE BY TIIE MIDWIFE}

Without a scientific method of caring, effective practice is accidental at best and haphazard or harmful at worst. A scientific method allows for control and prediction and it permits self-correction. Without it one resorts to the substitutes of trial and error, experience, intuition, common sense, faith, custom or habit (Watson, 1979:56).

Although the process of care by the midwife will be described in different steps, the steps are, however, not seperate because they happen continually throughout the contact that the midwife has with the family.

Midwifery care starts the moment that the midwife and the family meet one another. This initial contact is the stage during which she observes the family, communicates with them and gets to know them better. Subjective knowledge, from these initial observations and communication, colours impressions and perceptions of both the midwife and the family during this phase. Both parties begin to transcend their respective roles and perceive uniqueness in each other.

Tasks to be accomplished by the midwife during this phase, are to separate herself and her experiences from others and to avoid using herself as a yardstick to measure others. (Travelbee in Meleis, 1985:254).

She steps out of her own frame of reference into another's, considers the other's point of view, their objective needs and what they expect of her (Noddings, 1984:14-16); she can achieve this by doing an objective assessment of the family.

The assessment phase is, however, not only limited to this first encounter with the family but is a continuous process, till the relationship between the midwife and the family is ended.

The activities of care are grounded in a midwife's perception and judgement of the family's needs and health-related problems at a particular time (Griffen, 1983:292). She must know who the other persons are, what their powers and limitations are, what their needs are and what is conducive to their growth. She must understand the other's needs and she must know how to respond to their needs and what her own powers and limitations are (Mayerhoff, 1971:13).

The midwife may do her assessments continuously or she may respond to a feeling or an observation that something is the matter. Once alerted, the midwife attends to the family/member and begins with the collection of sufficient accurate data to formulate a nursing diagnosis.
The midwife's interpretation is of ten subjective, because it is influenced by her knowledge, skills, experience, values and beliefs. That is why is is so important that the midwife should step out of her own frame of reference into the family's and do her assessment from the family's standpoint (Watson, 1979:108).

Assessment therefore has cognitive, moral and emotional aspects and is objective, as wcll as intuitive (Griffen, 1983:292). It includes assessing all the aspects of the internal and external environments of the individual/family, as well as the way in which the individual/family are dealing with these aspects (ORU, 1989).

After the needs and problems have been determined, the midwife must use her knowledge to plan care that is applicable, to assist and facilitate the family 10 meet their needs, or solve the specific problems and reach the objectives of care.

The family's rights and responsibilities to participate actively in decisions and actions about their health care should be respected during the planning phase. The midwife should remember that overcaring can make the family dependent.

Planned care is implemented and evaluated continuously as well as at the end of the contact between midwife and family. Has growth towards maximum health taken place?

Documentation forms an integral part of each of the above steps and should be a complete reflection of the family's health as well as comply with the legal requirements of the country.

\section{CIIARACTERISTICS OF CARE}

It is difficult to define caring precisely. As a noun the dictionary states that it means trouble, anxiety, serious attention, heed, caution and pains.

As a verb the Concise Oxford Dictionary gives the meaning as feeling concern or interest, regard, deference, affection, liking.

Care is a science as well as an art and the practice of the science of caring in midwifery draws on basic knowledge and an understanding of how people feel and behave under various circumstances.

"Regardless of the area of nursing specialization the professional nurse has at her disposal a knowledge of human behaviour, biophysical processes, pathological processes, nursing skills and procedures and various treatment regimens. The synthesis of all those perspectives and all the data base in the care of a specific person, family or group actualises a science of caring" (Watson, 1979:52).
According to Bevis (1988:49-59), caring is an art because it possesses all threc elements of an art, namely:

* dedication and commitment to the art;

- study of the philosophy and theory of the art; and

- it practises a wide variety of expressions.

Kotzé (1979:175) states that the knowledge or science part of caring only becomes usable when it becomes an an. This becomes possible when the midwife uses her knowledge and herself therapeutically through movements, sense, touch, and sounds in the caring for the family.

"To use oneself therapeutically is an art and a science, it requires discipline as well as self insight, reasoning as well as empathy, logic as well as compassion... It implies the educated heart and the educated mind" (Travelbee in Kotzé, 1979: 175).

There are two main dimensions in the practice of caring, namely, an instrumental and an expressive dimension. The instrumental dimension includes all the actions of the midwife which lead to the concrete realization of her objectives. These actions can to a greater or lesser extent be technological while the expressive part of her task is based on the establishment of an environment and relation. that will contribute to realization of her objectives.

It is important that both of these dimensions should be present in everything that the midwife does.

Because man is seen as a unique individual with a spirit, body and mind and as one who functions on a biopsychosocial level, caring must have the same components. The individual is also part of a family which forms part of a greater community with specific values and beliefs.

Caring therefore has biophysical, psychological, cultural, social and environmental dimensions which must be taken into account to provide holistic care to people. Because the mother and baby form such an integral part of the family and the community, midwifery care must also be family- and community centred

\section{COMPREIIENSIVE CARE}

The South African Nursing Council (S.A.N.C.) supports the concept of a continuous, comprehensive health-care service (Health Act No 63 of 1977). Care therefore should have preventative, curative and rehabilitative components and the midwife should assist and facilitate the individual, family and community to promote, maintain and restore health.

Care never takes place in isolation, but has a time-space and cultural orientation; it may take 
place in hospital, clinics, at home or in the community. Care can alternately or continuously take place in any of the above-mentioned places, at any time during the child-bearing phase (Botes, 1989: 104).

Caring may also be described as actions ranging from self-care which a healthy person normally exercises for himself, to care provided by friends and family and to highly specialized care provided by professional midwives (McFarlane, 1988:10).

The midwife has to share the time-space context with other members of the health-team, because of the multi-dimensionality of midwifery care and health care in general (Botes, 1989:104).

Midwifery care has to take place within a definite ethico-legal framework, prescribed by the laws and regulations of the country. In the local context, the S.A.N.C. prescribes, and midwifery is executed on Christian principles; moral and ethical values provide a specific cultural context and depict norms according to which midwifery care adheres.

It is, however, not only this cultural context and these norms that determine care but will be determined also by the carer as well as the recipient's personal culture, value systems, norms and by structures in the community (compare Botes, 1989: 105; Watson, 1985 :II; Leininger, 1988a:9).

Care changes continuously because it is influenced by the people involved therein, the place, circumstances, technology and philosophy; scientific methods of nursing are processes which also indicate movement and change.

\section{TIIE CONSTITUENTS OF CARE}

The midwife should assist and facilitate the individual, family and community to promote, maintain and restore health.

The facilitating and assisting activities of the midwife include guidance, anticipatory guidance, support, education, the provision of an environment that promotes personal growth (compare Orem 1971: 78-77). accompaniment and the promotion of social support. These constituents, although listed separately, are applied collectively or separately, depending on the individual/family's biopsychosocial needs. Many of the constituents also have common attributes and overlap in many ways, for example guidance and teaching. All the actions lead to the maintenance, promotion and restoration of health, depending on the position of the family on the health continuum.

Guiding another as a method of assistance is valid in a situation in which the individual/family must make a choice or pursue a course of action in an area where they have a lack of knowledge and need direction or supervision (Muller, 1988: 35-36; Orem, 1971: 74).

Anticipatory guidance is the preparation and guidance of the person/family with regard to things that still have to happen (Pridham, Hansen \& Conrad 1977: 1077).

Guidance requires that the guided and the guide should be in communication with each other (Orem 1971: 74). People who are guided must be motivated and able to perform activities required. The actions of the midwife alone are no guarantee that the family will become independent; the family must be actively involved in the whole process getting the opportunity to practise knowledge and skills which they have learnt in decision-making, problem-solving, baby care and personal care.

The guidance must be appropriate according 10 the needs of the individual/family, whether in the form of suggestions, instructions, direction or supervision. Guidance usually goes hand in hand with support and education of the individual/family. (Orem, 1971: 74).

If there is no progress, but uncertainty which may lead to feelings of insecurity, the midwife will change the guidance to accompaniment. Guidance has direction and movement to reach specific objectives; accompaniment adds to this a relationship and togetherness based on trust.

When the family come into contact with the midwife, factors contributing to feelings of insecurity are often present or soon become present. Their insecurity makes the family look to the doctor and midwife for help and support and through accompaniment the family can be helped to feel secure. Accompaniment is therefore that part of care with the potential to lead people to accept responsibility for themselves and find meaning in their lives.

Accompaniment focuses mainly on the expressive part of the caring actions, but also forms a facet of every nursing act.

Principles of accompaniment adapted from Kotzé, (1979: 125): suggest that it is:-

* goal-directed and planned interaction to reach set objectives centring around the independence of the person in search for help. This implies the arousal of the responsibility and will to become independent;

- based on trust, which may become a relationship of trust. The accompanist can establish a milieu of trust encouraging the accompanied to lay bare that part of his personal world which he is willing to reveal;

- based on a relationship of authority in that the accompanist accepts the authority of norms which have a distinct bearing on his life and actions. This means that the adult should be a living example of norm exemplification and norm acceptation to the family.

The authority of the accompanist's knowledge implies that she knows the area that must be discovered and the implications thereof. The relationships of knowing and the relationship of trust are preconditions for the existence of the relationship of authority.

Acceptance of individual dignity and uniqueness is essential for the maintenance of this relationship which is bused on an agape love.

\section{TIIE PROCESS OF ACCOMPANIMENT}

Accompaniment itself takes place in different phases according to Kotzé, (1979: 150-190).

Phase 1:

The midwife and the family are together in the same area and become aware of one another.

- In her assessment of the family the midwife must be able to identify the moments where accompaniment of the family members may become necessary. She therefore must assess the degree to which the family have lost their independence and how they experience their parenthood. Observation and dialogue forms an important part of the diagnosis.

- The family should play an active part in the planning of accompaniment. In setting the priorities, the family's feelings of insecurity should be a priority.

\section{Phase 2:}

During this phase the midwife and family become closer to one another by means of their togetherness and communication with one another. A relationship of trust develops and the family communicates (verbally and non-verbally) their need for accompaniment to the midwife.

Phase 3:

The midwife can now help them to regain their security and get a grip on the reality of the situation by means of suggestions, education about the unknown and even by admonitions. The family should get recognition for everything that they do correctly.

\section{Phase 4:}

The midwife can determine by means of continuous evaluation whether the accompaniment goals have been met. If it has been successful they get back to phase 1, namely, a stage of togetherness. They stay in this state till the midwife identifies the next need for accompaniment. 


\section{Phase 5:}

When the family become independent, with victory over their needs for support, and responsibility for themselves, the midwife can leave the situation.

The family accept their experience and responsibility and do not try to escape the reality any more. As the midwife explains aspects of the situation to them and as uncertainties become clear, they leam how to deal with things without anxiety. They regain their grip on reality as they became involved in activities, and as they get the opportunity to make their own decisions.

A further necessary constituent of care is supporr. The dictionary definition of support is:- carry weight of, hold up, keep from falling or sinking, enable to last out, keep from failing, give strength to, encourage (Oxford Concise Dictionary). Support is not differentiated by certain words or tasks, but is part of the everyday contact with the child-bearing family and happens or is instituted only when there is a definite need for it. It helps the person to regain personal strength during periods which demand extra energy and resources (Brown, 1986: 4-9).

Various influential nurse writers suggest support that is characterised thus:-

- To support the family means to sustain them in their efforts and thereby prevent them from failing to cope with or from avoiding an unpleasant situation or decision (Orem 1971: 74).

- Support assists coping, adjustment, adaptation and problem-solving during life transitions (Brown, 1986: 4-9).

* The family in need is not alone, as the midwife is available to sustain them (Orem 1971: 74). An important aspect of support is the availability of the supporter in respect of time, strength, emotion and information. Even though distance may separate them as, for example, in the postnatal period, the individual/family need to know that the midwife is available (Kuhn, 1984: 93).

- It consists of the midwife communicating (verbally as well as nonverbally) that her training, experience and understanding are at the service of the developing individual or family (Wiess in Caplan, 1976: 214).

* It is also seen as helping the family to mobilize psychological resources and sharing the individual/family's task to improve or handle the situation (Caplan 1974 in Brown, 1986: 4-9).

- It assures the family that they are loved and valued as persons, regardless of achievements. It is an affirmation or endorsement of their behaviours, perceptions or expressed views (Kahn \& Antonucci in Brown 1986: 4-9).
* It is only a temporary action. In the meantime the family will be motivated to take responsiblity in accomplishing their tasks as soon as possible.

- Support can include different actions(House 1984 Brown, 1986: 4)

- Physical support - encouraging another person to initiate or persevere in performance of a task or to help the person performing the task that he/she can temporarily not perform because of a physical disability or lack of knowledge.

- Emotional support includes affection, trust, concern and listening and reassurance of one's worth (Connell \& D'Augelli, 1988: 108).

- Informational support includes advice, suggestions, information (Connell \& D'Augelli, 1988: 108).

- Instrumental support includes aid in terms of money labour and time.

- Spiritual support includes quotations and confessions from the Bible applicable to the situation, and prayer. The family's religious leaders can be contacted if they belong to other religions.

- The availability of someone in whom to confide.

The supporter's acceptance will depend upon her ability to convince the person in need of support that her training, knowledge and experience, understanding and commitment are available when needed (Ball 1987: 11).

Support by the midwife is one part of the whole interactive framework of support which an individual/family need if they are to make a successful and happy adjustment to parenthood. This interactive framework is formed by other people who offer support to the new mother, namely, family, friends and other members of society. They form the social support system of the new family (Ball, 1987: 121). These systems operate via the informal network of individual non-professional caregivers and through such organizations as religious denominations, fraternal associations, mutual assistance and self-help groups (Caplan, 1976: 20).

The midwife should enhance the capacity of the natural social support system. If such a social system does not exist or is insufficient, the midwife may encourage the formation of self-help groups to provide this support.

Social support is defined by Golllieb (1983: 28) as follows:

"Social support consists of verbal and/or nonverbal information or advice, tangible aid, or action that is proffered by social intimates or inferred by their presence and has beneficial emotional or behavioural effects on the recipient"

It implies 100, an enduring paltern of continuous or intermittent ties that play a significant part in maintaining the psychological and physical integrity of the individual over time (Caplan in Killilea, 1976: 41).

Heal th education is education intended to have a positive impact on health. It may be intentionally directed towards knowledge levels, attitudes or specific behaviours (Dignan, Carr \& Felinger, 1987: 5).

One of the indicators for growth on the health continuum is the family's capacity to make their own choices. This choice is based on many factors, including cultural beliefs, self-awareness and knowledge. Knowledge allows the family to make an informed choice about their health and health education seeks ways of providing this information in meaningful ways. It also helps to put people in touch with their own feelings about certain behaviours and an increase in self-awareness can facilitate change (Barnes, 1987: 6).

Teaching should be individualized and based on the unique needs of the family with a focus on teaching but rather on learning and interpersonal components (Watson, 1979: 74). Health education therefore should be based on the principles of problem-solving.

The midwife should provide or help to provide environmental conditions that motivate the family to establish appropriate goals for themsel ves and adjust their behaviour to achieve results specified by the goals (Orem, 1971:75).

The needed environmental conditions may be physical, mental or spiritual. It is the whole environment that makes it developmental and not only part of it (Orem, 1971: 75).

* The physical environment should be as homelike and as comfortable as possible. (Watson, 1979: 89).

The environment should also be as safe as possible and many of the midwife's activities are concerned with the physical components of safety. Her concern for safety, however, should include also knowledge, appreciation and tolerance of the behaviour that makes a person feel psychologically safe (Watson, 1979: 96).

* The mental environment should be as comfortable as possible. New stimuli should be introduced slowly so that the person gets time to know them. Giving the family the opportunity to talk and listening to them, are mentally comforting measures (Watson, 1979: 90).

Sociocultural comfort measures should be related to the normal behaviours and habitual ways of the family's culture and the midwife 
must consider the family's sociocultural values, beliefs and background in planning and providing comfort measures (Watson, 1979:91).

The depersonalization that occurs with hospitalization and the intimate questions, procedures, and treatments connected with hospitalization contribute to concerns regarding the privacy of the family. The expectation of the hospital staff that the mother will share intimate information and expose her body without reserve also contributes to the patient's loss of privacy. Humiliation, embarrassment and depersonalization are often the result of an invasion of privacy (Watson, 1979: 93).

- The spiritual environment - the midwife's acknowledgement, appreciation, and respect for the spiritual meaning in a family's life can be comforting to the family (Watson, 1985: 92).

The physical care which the midwife will implement will be according to the family's needs as well as the regulations of the Nursing Act (No.50 of 1978) which govern the scope of practice of South African midwives.

During the child-bearing phase families may experience a maturational as well as a situational crisis. A maturational crisis occurs during natural transitions in the developmental process, while situational crises follow unanticipated sudden events over which no control can be exerted, for example the death of a baby, or the birth of an abnormal baby. Because a crisis is a temporary state of upset, the aim of intervention is to promptly assist the family to resolve the situation so that growth, with an improved level of functioning, is achieved when equilibrium is regained (Stanhop \& Lancaster, 1988:656).

Crisis intervention is based on the problem-solving process. Information about the following aspects should be gathered during the assessment phase:-

- the precipitating event, resulting problems, the onset of the crisis, the impact of the crisis on the family, and on significant others, previous coping strategies, strengths of the family and individuals in the family's life who can provide support (Aguilera \& Messick, 1982; Hoff, 1978).

The intervention techniques used in crises are varied and include listening actively with concern, helping the family express feelings, exploring new ways of coping, helping the family find and use supports and assisting them to gradually accept reality. Immediate goals are set, workable plans of action are explored, and specific actions are chosen with the family. The family are responsible for the resolution of the crises (Aguilera \& Messick, 1982; Hoff, 1978).

\section{CONCLUSION}

Midwifery is an act of interaction between the midwife and the family and the most essential part of the interaction process is caring.

\section{BIBLIOGRAPIIY}

AFFONSO, D.D. AND ARIZMENDI, T.G 1986: Disturbances in postpartum adaptation and depressive symptomatology. Journal of Psycosomatic Obstetrics and Gynaecology. 5, 1986: 15-32.

AGUILERA, D. AND MESSICK, J. 1982 : Crisis intervention, theory and methodology, fourth edition. St Louis C.V. Mosby

ANDERSON, C. 1976: Operational Definition of Support. Journal of obstetrical gynaecological and neonatal nursing. Jan/Feb 1976: 17-18.

BALL, J.A. 1987: Reactions to motherhood The role of the postnatal care. Cambridge. Cambridge University.

BARNES, A. 1987: Personal and community health. Third edition. London. Boulliere Mundall.

BEVIS, E. O. 1988: Caring: A life force in Leininger M.M. (ed) 1988: Caring an essential human need. Detroit Wayne State University.

BOTES, A. 1990 : 'n Model vir wetenskapsbeoefening in die verpleegkunde. Proefskrif ter vervulling van die graad D.Cur, Randse Afrikaanse Universiteit. Johannesburg.

BOYLE, J.S. 1988: An application of the structural functional method in Leininger M.M. (ed) 1988: Caring an essential human need. Detroit Wayne State University.

BROWN, M.A. 1986: Social support during pregnancy: A unidimensional or multi dimensional construct? Nursing Research 35(1), Jan/Feb. 1986: 4-9.

BULL, M. AND LAWRENCE, D. 1985: Mother's use of knowledge during the first postpartum weeks. Joumal of Obstetricah Gynaecological and Neonatal Nursing. Jul/Aug. 1985: 315-321.

CAPLAN, G. 1976 : The family as support system. in Caplan, G. and Killilea, M. (ed) 1976: Support systems and mutual help. Multidisciplinary explorations. New York. Grune \& Stratton.

CONCISE OXFORD DICTIONARY 1946 : Third edition. London. Oxford University.

CONNELL, C.M. AND D'AUGELLI, A.R. 1988: Social support and human development: Issues in theory, research and practice. Journal of Community Health, 13(2), Summer 1988: 104-114.

DIGNAN, M. CARR, P.A. AND FELINGER, S. 1987: Program planning for health education and health promotion. Philadelphia.

DONALDSON, N.E. 1981 : The postpartum follow-up nurse clinician. Journal of Obstetrical, Gynaecological and Neonatal Nursing. 10(4), Jul/Aug. $1981: 249-254$

DUNLOP, MJ. 1986: Is a science of caring possible? Journal of advanced nursing. 11. 1986: 661-670.

FRANKL, V.E. 1965: The doctor and the soul. Second edition. London. Souvenir.

GARDNER. K.G. AND WHEELER, E. 1988 : The meaning of caring in the context of nursing, in Leininger M.M. (ed) 1988: Caring an essential human need. Detroit Wayne State University.

GAUT, D.A. 1983 : Development of a theoretical adequate description of caring. Western Journal of Nursing Research. 5(3), 1983: 313 - 323.

GOTTL.IEB, B.H. 1983 : Social support strategies. Guidelines for mental health practice. Beverly Hills. SAGE Publications, Inc.

GRIFFIN, A.P. 1983: A phylosophical analysis of caring in nursing. Journal of advanced nursing, 1983; 8: 289-295.

HAMPSON, S.J. 1989: Nursing interventions for the first three postpartum months. Journal of Obstetrical, Gynaecological and Neonatal Nursing. Mar/Apr. 1989: 116-121

HOFF, L.A. 1978 : People in crisis, understanding and helping. Menlo Park. Addison Wesley Publishing

JOHNSON, R. 1983 : Using crisis intervention wisely. Pennsylvania. Nursing 83 books.

KALLILEA, M. 1976: Mutual help organizations: Interpretations in the literature. in Caplan, G. and Killilea, M. (ed) 1976: Support systems and mutual help. Multidisciplinary explorations. New York. Grune \& Stratton.

KITSON, A.L. 1987: A comparative analysis of lay-caring and professional (nursing) caring relationships. International Journal of Nursing Srudies, 24(2), 1987: 155-165.

KOTZÉ, W.J. 1979 : Begeleiding in verpleegkunde. Pretoria. S.A.V.V.

KONRAD, C.J. 1987: Helping mothers integrate the birth experience. MCN. Jul/Aug.1987: 268-269. 
KUHN, J. 1984: Updating Family/Centered Maternity care: Application of a conceptual analysis of support. Healih care for Women International. 1984: 93-101.

LARYEA, M.G.G. 1984: Postnatal care. The midwife's role. Edinburgh. Churchill Livingstone.

LEININGER, M.M. 1988a : The phenomenon of caring: Importance, research questions and theoretical considerations in Leininger M.M. (ed) 1988 : Caring an essential human need. Detroit Wayne State University.

LEININGER, M.M. 1988b : Cross cultural hypothetical functions of caring and nursing care in Leininger M.M. (ed) 1988 : Caring an essential human need. Detroit Wayne State University.

LEMMER, C.M. 1986 : Early discharge : outcomes of primiparas and their infants. Journal of Obstetrical, Gynaecological and Neonatal Nursing. 1987 : 230-236.

LYN, M.R. 1986 : Determination and quantification of content validity. Nursing Research, 35(6), 1986: 382-385.

MAYEROFF M. 1971 : On caring. New York. Harper \& Row Publishers.

MARECKI, M.P. 1979: Postpartum follow-up goals and assessment. Journal of Obstetrical, Gynaecological and Neonasal Nursing 1979: 214-218.

McFARLANE, J. 1988: Nursing: A paradigm of caring. in Fairbum, G. and Fairbum, $S$. (ed) 1988: Ethical issues in caring. Hants. Avebury.

McKENZIE, C.A. CANADY, M.E. AND CARROLL, E. 1982: Comprehensive care during the postpartum period. Nursing Clinics of North America. 17(1), 1982: 23

MELEIS, A.I. 1985 : Theoretical nursing. Development and progress. Philadelphia. J.B. Lippincott

MULLER, E.C.C. (ed) 1985: Interaksie analise. Opleidings-instrumente vir onderwysstudente. Pretoria. HAUM

MULLER, M.E. (ed) 1990: Gehalteversekering in privaathospitale: 'n verpleegkundige perspekticf. Doktorale proefskrif, Randse Afrikaanse Universiteit. Johannesburg.

NODDINGS, N. 1984 : Caring. A feminine approach to ethics and moral education. Berkeley. University of California

OREM, D.E. 1971: Nursing: Concepts and practice. Scarborough, Ontario. McGraw-Hill.

ORU (ORAL ROBERTS UNIVERSITY, ANNA VAUGHN SCHOOL OF NURSING) 1989: A syllabus and general guide for theories in nursing. Fall Semester 1989.

POGGENPOEL, M. 1989: Psychiatric nursing conceptual model. Research report. Johannesburg. Rand Afrikaans University.

PRIDHAM, H.F. HANSEN, M.F. AND CONRAD, H.H. 1977: Anticipatory care as problem-solving in family medicine and nursing. The Journal of Family Practice, 4(6), 1977: 1077-1081.

RAY, M.A. 1988 : A philosophical analysis of caring within nursing in Leininger, M.M. (ed) 1988: Caring an essential human need. Detroit Wayne State University.
RIEMAN, DJ. 1986: The essential siructure of a caring interaction: Doing phenomenology in Munhall, P.L. and Oiler, C.J. 1986: Nursing research a qualitative perspective. Norwalk. Appleton Century Crofts.

SHEEHAN, F. 1981: Assessing postpartum adjustment. A pilot study. Journal of Obstetrical, Gynaecological and Neonatal Nursing. 1981: 19-23.

STANHOPE, M. AND LANCASTER, J. 1988: Community health nursing. Process and practice for promoting health. Second edition. St Louis. C.V. Mosby.

STUART, B. AND JUDGE, 1984: The return of the midwife. Midwives Chronicle and Nursing Notes, 97(1): 8.

SUMNER, G. AND FRITCH, J. 1977: Post-natal parental concerns: The first six weeks of life. Journal of Obstetrical, Gynaecological and Neonatal Nursing. 1977:27-31

WATSON, J. 1979 : Nursing: The philosophy and science of caring. Boston. Little Brown Company.

WEISS, R.S. 1976: Transition states and other stressful situations: Their nature and programs for their management. in Caplan, G. and Killilea, M. (ed) 1976: Support systems and mutual help. Multidisciplinary explorations. New York. Grune \& Stratton.

D Litt et Phil (Nursing) (UNISA)

Professor Department of Nursing Science

Rand Afrikaans University, Johannesburg 